\title{
Zooplankton community structure of the lower Xingu River (PA) related to the hydrological cycle
}

\author{
Matsumura-Tundisi, T. ${ }^{a *}$, Tundisi, JG. ${ }^{a, b}$, Souza-Soares, $F^{a}{ }^{a}$ and Tundisi, JEM. ${ }^{a}$ \\ ${ }^{a}$ Associação Instituto Internacional de Ecologia e Gerenciamento Ambiental - AIIEGA, \\ Rua Bento Carlos, 750, Centro, CEP 13560-660, São Carlos, SP, Brazil

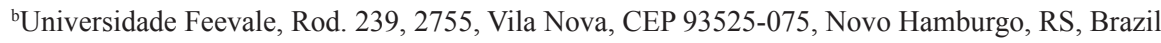 \\ *e-mail: takako@iie.com.br
}

Received: September 13, 2015 - Accepted: September 15, 2015 - Distribuited: August 31, 2015

(With 3 Figures)

\begin{abstract}
The zooplankton community of the lower Xingu River shows strong fluctuations in species richness and number of organisms during periods of water level fluctuation. Pulses of density and species richness are adapted to the pulses in water flows and water level. This is conected with reproductive strategies of some zooplankton groups. The spatial heterogeneity of the lower Xingu River consisting of braided channels, bedrocks, macrophyte stands, is probably a relevant factor for the species richness of the zooplankton communities, and may be a fundamental factor for the overall aquatic biodiversity of the lower Xingu River.
\end{abstract}

Keywords: Lower Xingu River, hydrological cycle, zooplankton richness, endemic species, reproductive strategies.

\section{Estrutura da comunidade do zooplancton do Baixo Rio Xingu (PA), em relação ao ciclo hidrológico}

\section{Resumo}

A comunidade zooplanctônica do Baixo Rio Xingú apresenta grandes flutuações em riqueza de espécies e na densidade $\left(\mathrm{n}^{\circ}\right.$ org. $\left./ \mathrm{m}^{3}\right)$ durante os diferentes períodos de flutuação do nível da água. Pulsos de densidade e de riqueza de espécies, são adaptados e ajustados aos pulsos em nível da água e fluxo. Isto está conectado com as estratégias reprodutivas de certos grupos de zooplancton. A heterogeneidade espacial do baixo Rio Xingú consistindo de canais anastomosados, pedrais, macrófitas aquáticas é provavelmente um fator relevante que impulsiona a riqueza de espécies das comunidades zooplanctõnicas e pode ser um fator fundamental para a alta biodiversidade aquática do Rio Xingú.

Palavras-chave: Baixo Rio Xingú, ciclo hidrológico, riqueza de zooplancton, espécies endêmicas, estratégias reprodutivas.

\section{Introduction}

It is well known that river discharges have influence in the aquatic biota of rivers due to changes in channel morphology, habitats, deposition of sediments, organisms drift and water level fluctuations. Benthic invertebrates, fishes, zooplankton, periphyton all respond to the temporal variability of the river system, that depends upon the regional hydrological cycle (Petts and Amoros, 1996; Dumont, 2009; Blettler et al., 2012, Abrial et al., 2014).

The lower Xingú River has strong water level fluctuations due to differential discharges throughout the year. Interactions between the zooplankton community and the river discharge in this ecosystem was studied by Brito (2008).

Carvalho (1983) demonstrated that the density and composition of zooplankton in a floodplain lake in Amamzonia is related to water level fluctuation.
The present study is framed into the field of ecological dynamics, in an attempt to provide an insight of the integration of hydrology, ecology and zooplankton community structure.

Zooplankton sampling and analysis were performed within an área of $10.000 \mathrm{~km}^{2}$ within the framework of the environmental impact assessment of Belo Monte reservoir, in the lower Xingu River carried out by Norte Energia S.A. The zooplankton studies are part of limnological, water quality and aquatic ecology research developed by Associação Instituto Internacional de Ecologia e Gerenciamento Ambiental (AIIEGA, 2015).

As defined by Bittencourt and Amadio (2007), the hydrologial cycle in the Amazon is composed by four hydrological periods: rising- water entering the river system and increasing water level from mid December to beggining of March, with change between 20 to $26 \mathrm{~m}$ above sea level; high - water level equal or above to $26 \mathrm{~m}$ 
above sea level from beggining of March to the end of July; reciding - water leaving the river system and water levels falling from the end of July to the end of October between 26 and $20 \mathrm{~m}$ above the sea level; low-water level equal or below $20 \mathrm{~m}$ above sea level from the end of October to mid December.

\section{Material and Methods}

A general description of the overall sampling strategy adopted for limnological and ecological studies was described by Tundisi et al. (In press, this volume). Figure 1 shows the average monthly flow, total precipitation (monthly) and sampling periods. The four periods of hydrological cycle adopted was: rising (November, December, January) flood, (February, March, April), lowing (May, June, July) and dry (August, September, October) periods.

A total of 37 stations were distributed along the lower Xingu River including the main chanel, tributaries and igarapés.

\section{Results}

3.1. Composition, density and richness of zooplankton related to the hydrological cycle

The most abundant group, numerically in all samples was Rotifera. Figure 2a,b show the relative abundance between Rotifera, Cladocera, Copepoda and Protozoa groups occurred in 2013 (Figure 2a) and in 2014 (Figure 2b). Generally the Rotifera independent of the hydrological cycle, represented $40-50 \%$ of the total zooplankton. Exception occurred during the high water in 2013 (Figure 2a) where Rotifera was substituted by Tecameba protozoan which dominated the zooplankton (47.4\%) and Copepoda (35.3\%) especially in this case in the phase of nauplii. Also in the dry period of 2014, Rotifera was outnumberd by Cladocera that represented $48.0 \%$ of the total zooplankton whereas Rotifera was $30,0 \%$. The high percentage of Cladocera was due to the very high growth of Bosminopsis deitersi population.

Comparing the absolute density of planktonic organisms (ind $/ \mathrm{m}^{3}$ ) in 2013 and 2014 (Figure 3a, b) there were

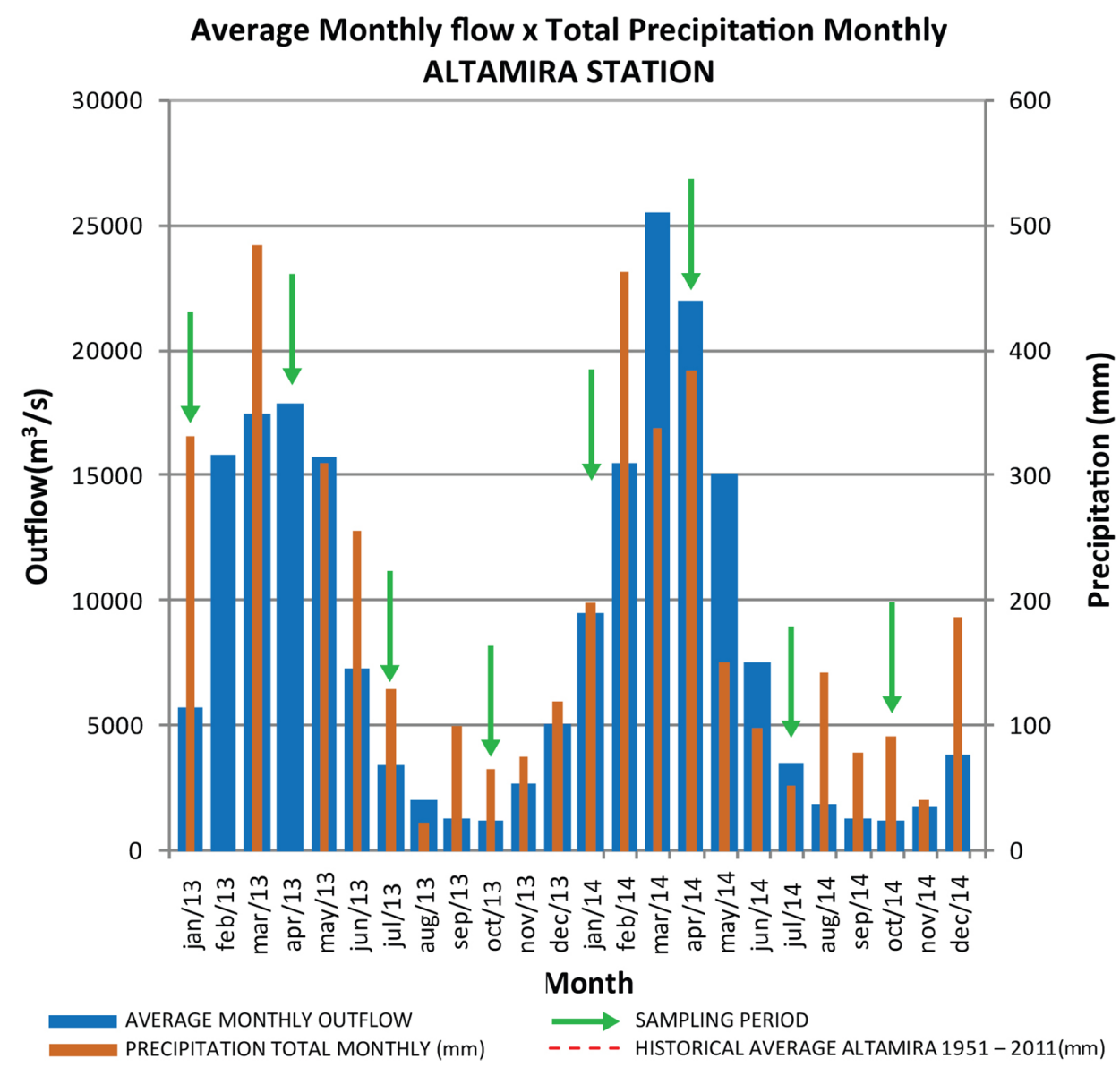

Figure 1. Four hydrological periods: rising (November, December, January); flood (February, March, April); lowing (May, June, July); dry (August, September, October), related to the outflow $\left(\mathrm{m}^{3} / \mathrm{s}\right)$ and precipitation $(\mathrm{mm})$. The arrows show the sampling month carried out, during 2013 and 2014 (From: Norte Energia S.A.). 


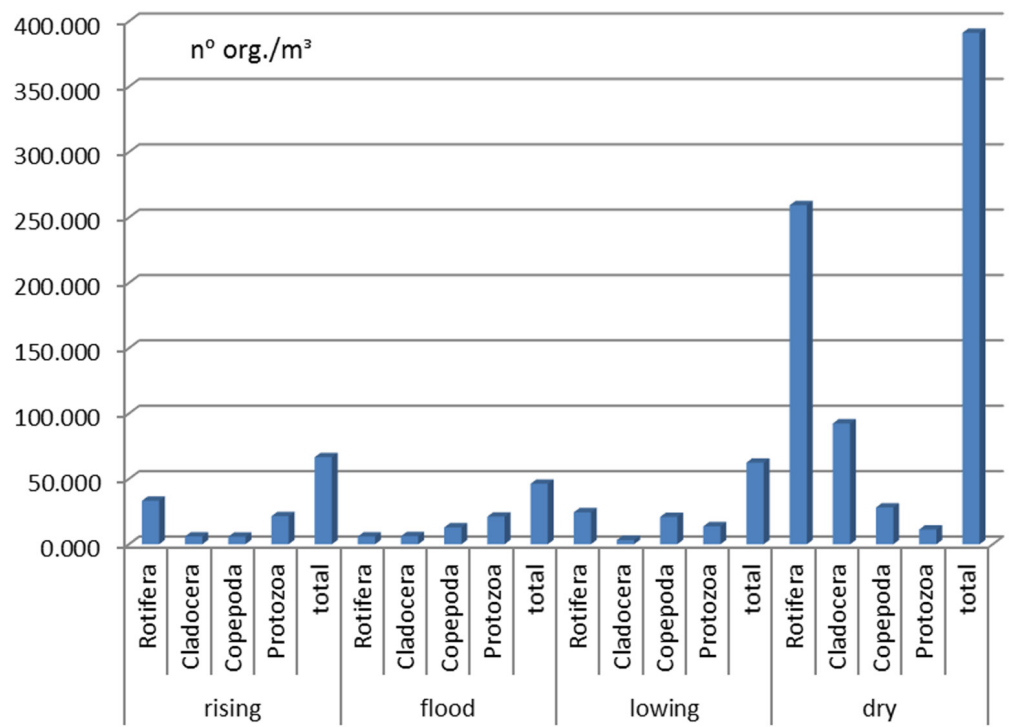

(a) 2013

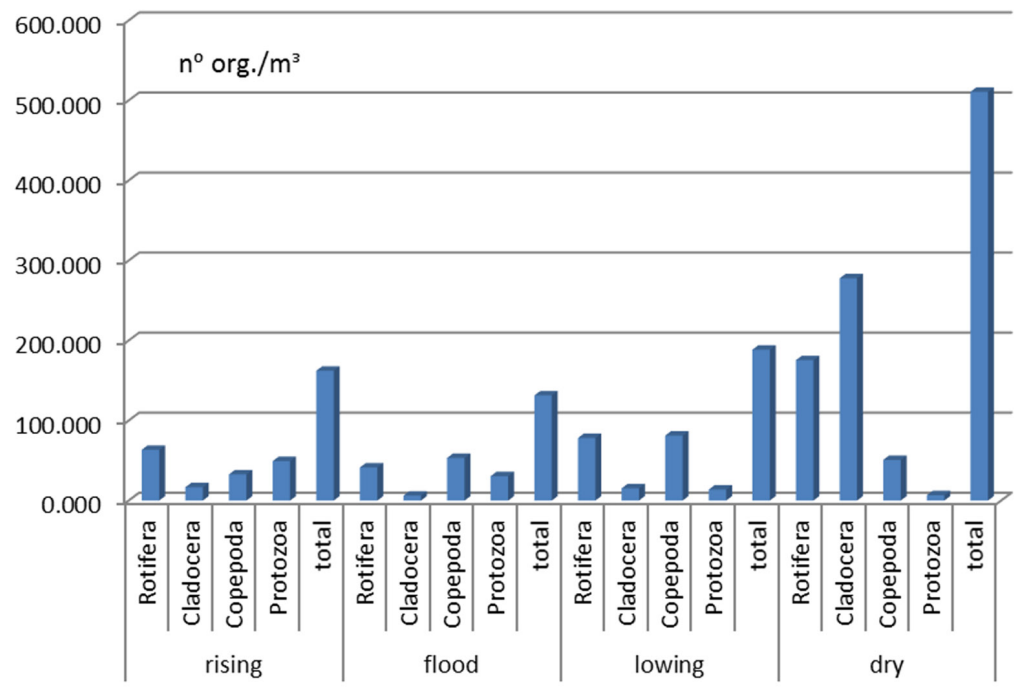

(b) 2014

Figure 2. Zooplankton density $\left(\mathrm{n}^{\circ} \mathrm{org} . / \mathrm{m}^{3}\right.$ ) total and per group (Rotifera, Cladocera, Copepoda and Protozoa occurring in different phases of hydrologial cycle in 2013 (a) and in 2014 (b).

higher number of organisms in 2014 with $510,749 \mathrm{org} / \mathrm{m}^{3}$ (Figure 3b) than in 2013 with 391,187org./ $\mathrm{m}^{3}$ (Figure 3a). In both cases high density of total zooplankton occurred during the dry period due to the increasing of number of Rotifera, Cladocera and Copepoda.

Tables 1, 2, 3 and 4 refer respectively to the list of species of Rotifera, Protozoa, Cladocera and Copepoda found in the samples of 2013 and 2014.

Among the Rotifera (Table 1), 94 species were registered. The ten (10) more abundant in order of number of individuals were: Brachionus zahniseri (136,868 ind $\left./ \mathrm{m}^{3}\right)$; Polyarthra vulgaris $\left(80,716\right.$ ind $\left./ \mathrm{m}^{3}\right)$; Brachionus caudatus $\left(71,194 \mathrm{ind} / \mathrm{m}^{3}\right.$; Lecane proiecta $\left(65,132 \mathrm{~m}^{3}\right)$; Keratella americana $\left(29,108 \mathrm{ind} / \mathrm{m}^{3}\right)$; Pitygura libera $\left(20,133 \mathrm{ind} / \mathrm{m}^{3}\right)$; Conochilus coenobasis $\left(14,734 \mathrm{ind} / \mathrm{m}^{3}\right)$; Synchaeta stylata $\left(14,699 \mathrm{ind} / \mathrm{m}^{3}\right)$; Filinia limnetica $\left(10,728 \mathrm{ind} / \mathrm{m}^{3}\right)$ e Lecane curvicornis $\left(8,352 \mathrm{ind} / \mathrm{m}^{3}\right)$.

Among Protozoa (Table 2) it was recorded 49 species where the most abundant species were Centropixis aculeata $\left(27,818 \mathrm{ind} / \mathrm{m}^{3}\right) ;$ Arcella rotundata alta $\left(10,074 \mathrm{ind} / \mathrm{m}^{3}\right)$; Arcella vulgaris $\left(6,156 \mathrm{ind} / \mathrm{m}^{3}\right)$; Difflugia lobostoma $\left(3,625 \mathrm{ind} / \mathrm{m}^{3}\right)$; Arcella gibbosa $\left(3177 \mathrm{ind} / \mathrm{m}^{3}\right)$.

Among Cladocera (Table 3) 61 species were recorded from which the following species were most abundant and most frequent: Bosminopsis deitersi with $373,508 \mathrm{ind} / \mathrm{m}^{3}$, corresponding to $88.1 \%$ of total cladocerans registered; 


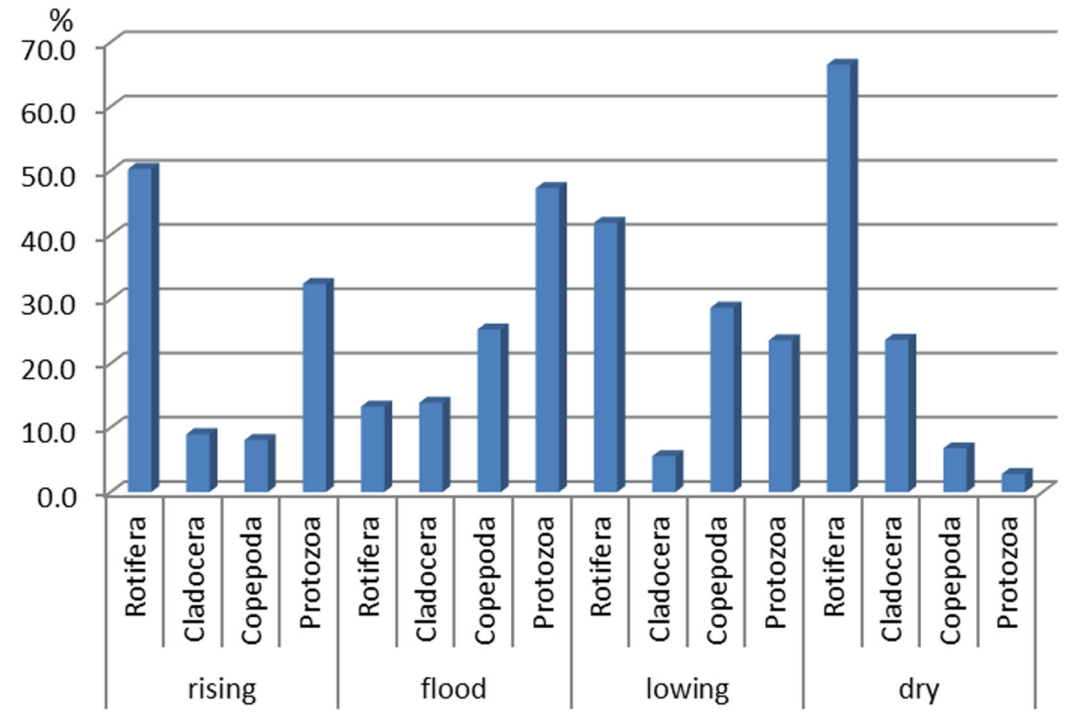

(a) 2013

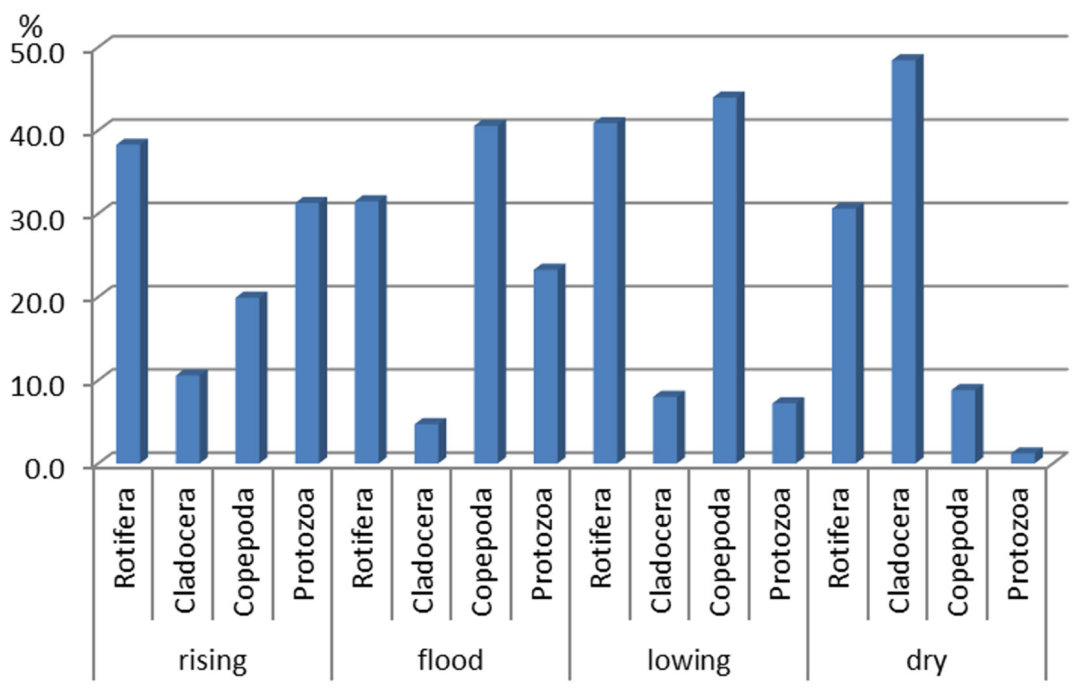

(b) 2014

Figure 3. Relative abundance (\%) of the main zooplankton groups (Rotifera, Cladocera, Copepoda and Protozoa), related to the hydrological cycle period in (a) 2013 and in (b) 2014.

Moina minuta with $15,008 \mathrm{ind} / \mathrm{m}^{3}$; Moina reticulata with $6,188 \mathrm{ind} / \mathrm{m}^{3}$; Moina micrura with $4,876 \mathrm{ind} / \mathrm{m}^{3}$; Ilyocryptus spinifer with 1,462 ind $/ \mathrm{m}^{3}$; Alona yara with $1,209 \mathrm{ind} / \mathrm{m}^{3}$ and Bosminopsis brandorffi with 1,013 ind $/ \mathrm{m}^{3}$.

For the Copepoda group (Table 4) there were identified four species of Cyclopoida: Mesocyclops meridianus, Macrocyclops sp, Thermocyclops minutus and Thermocyclops inversus and six species of Calanoida: Pseudodiaptomus gracilis, Notodiaptomus paraensis, Notodiaptomus dahli, Notodiaptomus oliverai, Notodiaptomus isabelae and Notodiaptomus jatobensis. The analysis for this group was carried out separating for Cyclopoida and Calanoida including the phase of naupliae, copepodits and adult.
Table 5 shows zooplankton species richness recorded at the four phases of the hydrological cycle, showing more richness in the rising and flood periods than lowering and dry periods for both years $2013 / 2014$. The decreasing of number of species during the dry period is clear for all the groups especifically for cladocerans and copepods.

\subsection{Endemic species of the Amazonian region}

Species that are restricted to one geographical or a hydrographic basin are considered endemic. In the lower Xingu River, Brachionus zahniseri, among rotifers, Bosminopsis brandorffi among cladocerans, Pseudodiaptomus gracilis, Notodiaptomus dahli, Notodiaptomus paraensis 
Table 1. List of Rotifera species recorded in the lower Xingu River. The subscribed species were the most abundant (more than $\left.50.000 \mathrm{org} . / \mathrm{m}^{3}\right)$ and more frequent occorrence during the period of study (2013-2014).

\begin{tabular}{|c|c|}
\hline Anuraeopsis fissa (Gosse, 1851) & Lecane lunaris Ehrenberg, 1932 \\
\hline Anuraeopsis navicula Rousseelet, 1910 & Lecane monostyla (Daday, 1897 \\
\hline Asplanchna sieboldi (Leydig, 1845) & Lecane nigeriensis Seger, 1993 \\
\hline Asplanchna sp (Gosse, 1850) & Lecane papuana Murray, 1913 \\
\hline Bdelloidea sp & Lecane pertica Harring \& Myers, 1926 \\
\hline Beauchampiella eudactylota (Gosse) & Lecane proiecta (Hauer, 1956) \\
\hline Brachionus ahlstromi (Lindeman, 1939) & Lecane quadridentata (Ehrenberg, 1832) \\
\hline Brachionus angularis Gosse, 1851 & Lecane rhenana Hauer, 1929 \\
\hline Brachionus bidentata (Anderson) & Lecane signifera (Jennings, 1896) \\
\hline Brachionus calyciflorus Pallas, 1866 & Lecane stenroosi (Meissner, 1908) \\
\hline Brachionus caudatus Barrois \& Daday, 1894 & Lecane thienemanni Hauer,1938) \\
\hline Brachionus dolabratus Harring, 1915 & Lepadella cristata (Rousselet, 1893) \\
\hline Brachionus falcatus Zacharias, 1898 & Lepadella donneri Koste, 1972 \\
\hline Brachionus quadridentatus Herman, 1783 & Lepadella imbricata (Harring) \\
\hline Brachionus variabilis (Hempel) & Lepadella ovalis (O.F.Müller,1786) \\
\hline Brachionus zahniseri Ahstrom, 1934 & Lepadella patella (O.F. Müller,1786) \\
\hline Cephalodella sp (Bory de St Vincent,1826) & Lepadella sp (Bory de St. Vincent, 1826) \\
\hline Collotheca sp (Harring, 1913) & Macrochaetus collinsii (Gosse, 1867) \\
\hline Conochilus coenobasis (Hlava) & Monommata appendiculata Stenroos, 1898 \\
\hline Conochilus unicornis (Hlava) & Monommata sp (Bartsch, 1870) \\
\hline Dicranophorus sp (Nitzch, 1827) & Mytilina acanthophora (Hauer, 1938) \\
\hline Dipleuchlanis propatula (Gosse, 1886) & Mytilina bisulcata (Lucks, 1912) \\
\hline Euchlanis dilatata Ehrenberg, 1834 & Mytilina macrocera (Jennings, 1894) \\
\hline Euchlanis lyra (Hudson, 1886) & Mytilina mucronata (Müller, 1773) \\
\hline Euchlanis meneta (Myers, 1930) & Mytilina ventralis (Ehrenberg, 1832) \\
\hline Euchlanis sp (Ehrenberg, 1832) & Plationus patulus (Müller, 1786) \\
\hline Euchlanis triquetra (Ehrenberg, 1838) & Platyias leloupi (Gillard, 1967) \\
\hline Filinia limnetica (Zacharias, 1893) & Platyias quadricornis (Ehrenberg, 1932) \\
\hline Filinia opoliensis (Zacharias, 1898) & Platyias quadricornis brevispinus Daday \\
\hline Filinia terminalis (Plate, 1886) & Ploesoma truncatum (Levander, 1894) \\
\hline Hexarthra intermedia brasiliensis (Hauer,1953) & Polyarthra dolichoptera Idelsom, 1925 \\
\hline Horaella sp (Donner,1949) & Polyarthra longiremis (Carlim, 1943) \\
\hline Keratella americana Carlin, 1943 & Polyarthra vulgaris Carlin 1943 \\
\hline Keratella cochlearis Gosse, 1851 & Ptygura libera Myers, 1934 \\
\hline Keratella tropica (Apstein, 1907) & Synchaeta stylata Wierzejski, 1893 \\
\hline Lecane aculeata (Akubski, 1912) & Synchaeta sp (Ehrenberg, 1832) \\
\hline Lecane bulla (Gosse, 1886) & Testudinella patina var. dendradena (Hermann, 1783) \\
\hline Lecane clara (Bryce, 1892) & Testudinella mucronata (Gosse) \\
\hline Lecane cornuta (Müller, 1786) & Trichocerca bicristata (Gosse, 1887) \\
\hline Lecane curvicornis (Murray, 1913) & Trichocerca cylindrica chattoni (Beauchamp, 1907) \\
\hline Lecane elsa (Hauer, 1931) & Trichocerca dixon nuttalli (Jennings, 1903) \\
\hline Lecane hamata (Stockes, 1896) & Trichocerca elongata ( Gosse, 1886) \\
\hline Lecane hastata (Murray, 1913 & Trichocerca inermis (Gosse, 1886) \\
\hline Lecane hornemanni ( Ehrenberg, 1834) & Trichocerca longiseta (Schrank, 1802) \\
\hline Lecane leontina (Turner, 1892 ) & Trichocerca myersi (Hauer, 1931) \\
\hline Lecane ludwigi (Eckstein, 1883) & Trichotria tetractis (Ehrenberg, 1830) \\
\hline Lecane luna (O.F. Müller, 1776) & Trichocerca sp \\
\hline
\end{tabular}

among copepods are considered endemic species of the Amazon region, because they were not registered in any other geographical regions or hydrographic basins of Brazil.

Pseudodiaptomus gracilis found at two stations in the lower Xingu River (Matsumura-Tundisi and Tundisi, 2007), is probably an endemic species of the Amazon region, restricted to it. The species is living in freshwater as opposite to Pseudodiaptomus acutus and Pseudodiaptomus richardi that are dwellers from brackish water and can tolerate high salinity. According to these authors Pseudodiaptomus gracilis can survive both in localities of low conductivity $\left(21.0 \mu \mathrm{S} . \mathrm{cm}^{-1}\right)$ as in high conductivity $\left(90.0 \mu \mathrm{S} . \mathrm{cm}^{-1}\right)$ as has been recorded in the Bacaja river a tributary of the Xingu River. 
Table 2. List of Protozoa species recorded in the sampling of the lower Xingu River during the period 2013-2014. The subscribed species were the most abundant species (more than $3000 \mathrm{ind} / \mathrm{m}^{3}$ ) that occurred in that period.

\begin{tabular}{|c|c|}
\hline Arcella artocrea $\mathbf{L e i d y , ~} \mathbf{1 8 7 6}$ & Difflugia acuminata Ehrenberg, 1838 \\
\hline Arcella conica (Playfair, 1918) & Difflugia acutissima Deflandre, 1931 \\
\hline Arcella costata Ehrenberg, 1847 & Difflugia bidens Penard, 1902 \\
\hline Arcella crenulata Deflandre, 1928 & Difflugia brevicolla Cash \& Hopkins, 1909 \\
\hline Arcella dentata Ehrenberg, 1838 & Difflugia bryophila (Penard, 1902) \\
\hline Arcella discoides Ehrenberg, 1871 & Difflugia corona Wallich, 1864 \\
\hline Arcella gibbosa Pénard 1890 & Difflugia cylindrus (Thomas)Ogden, 1893 \\
\hline Arcella hemisphaerica Perty, 1852 & Difflugia distenda Ogden, 1983 \\
\hline Arcella hemisphaerica undulata Deflandre, 1928 & Difflugia elegans Pénard 1890 \\
\hline Arcella megastoma Pénard, 1913 & Difflugia gramen Pénard, 1902 \\
\hline Arcella mitrata Leidy, 1879 & Difflugia lacustris (Penard,1899) \\
\hline Arcella rotundata alta Playfair, 1918 & Difflugia lanceolata (Penard, 1890) \\
\hline Arcella vulgaris Ehrenberg, 1830 & Difflugia litophila Pénard, 1902 \\
\hline Arcella vulgaris undulata Deflandre, 1928 & Difflugia lobostoma Leidy, 1877 \\
\hline Centropyxis aculeata (Ehrenberg, 1830) & Difflugia lobostoma multilobata Gauthier-Liève \& Thomas, 1958 \\
\hline Centropyxis aculeata oblonga Deflandre, 1929 & Difflugia mammillaris Pénard, 1902 \\
\hline Centropyxis aerophila Deflandre, 1929 & Difflugia microclaviformis (Kourov, 1925) \\
\hline Centropyxis cassis (Wallich, 1864) & Difflugia oblonga Ehrenberg, 1838 \\
\hline Centropyxis constricta (Ehrenberg, 1841) & Difflugia penardi Hopkinson,1909 \\
\hline Centropyxis discoides Pénard, 1890 & Difflugia urceolata Carter 1864 \\
\hline Centropyxis ecornis (Ehrenberg, 1841) & Diflugia sp \\
\hline Centropyxis gibba Deflandre, 1929 & Lesquereusia sp (Schlumberger, 1845) \\
\hline Centropyxis marsupiformis (Wallich) Deflandre, 1929 & Pontigulasia sp (Rhumbler, 1896) \\
\hline $\begin{array}{l}\text { Centropyxis platystoma Pénard, } 1890 \\
\text { Difflugia achlora Pénard, } 1902\end{array}$ & Protocucurbitella coroniformis Gauthier-Liève \& Thomas, 1960 \\
\hline
\end{tabular}

Table 3. List of Cladocera species found in the lower Xingu River, during the period 2013-2014. The subscribed species were the most abundant e frequent species that occurred on the sampling of that períod.

\begin{tabular}{|c|c|}
\hline Acroperus harpae Baird, 1843 & Diaphanosoma polyspina Korovchindky 1982 \\
\hline Alona dentifera (Sars, 1901) & Diaphanosoma spinulosum Herbst, 1967 \\
\hline Alona glabra (Sars, 1901) & Disparalona leptorhyncha (Smirnov, 1996) \\
\hline Alona guttata Sars, 1862 & Ephemeroporus sp \\
\hline Alona intermedia (Sars,1901) & Ephemeroporus tridentatus Bergamin, 1931) \\
\hline Alona ossiani (Sinev, 1998) & Euryalona brasiliensis Brehm \& Thomsen, 1936 \\
\hline Alona setigera $($ Brehm, 1931) & Graptoleberis ocidentalis (Sars, 1901) \\
\hline Alona yara (Sinev \& Elmor-Loureiro,2010) & Graptoleberis testudinaria (Fisher, 1851) \\
\hline Alonella clathratula Sars, 1896 & Ilyocryptus spinifer Herrick, 1882 \\
\hline Alonella dadayi & Karualona muelleri (Richard, 1897) \\
\hline Alonella poppei (Richard, 1897) & Karualona sp \\
\hline Biapertura rigicaudis Richard, 1897) & Kurzia polyspina (Hudec, 2000) \\
\hline Bosmina hagmanni Stingelin, 1904 & Leydigiopsis megalops Sars, 1901 \\
\hline Bosmina longirostris (O.F. Müller, 1785) & Macrothrix laticornis (Jurine, 1820) \\
\hline Bosmina tubicen Brehm, 1953 & Macrothrix sp \\
\hline Bosminopsis brandorffi Rey \& Vasquez, 1989 & Macrothrix spinosa King, 1853 \\
\hline Bosminopsis deitersi Richard, 1895 & Macrothrix superaculeata (Smirnov, 1992) \\
\hline Camptocercus dadayi Stingelin, 1913 & Macrothrix triserialis (Brady, 1886) \\
\hline Ceriodaphnia cornuta cornuta Sars, 1886 & Moina micrura Kurz, 1874 \\
\hline Ceriodaphnia cornuta rigaudi Sars, 1886 & Moina minuta Hansen, 1899 \\
\hline Ceriodaphnia richardi Sars, 1901 & Moina reticulata (Daday, 1905) \\
\hline Ceriodaphnia $\mathrm{sp}$ & Moina rostrata McNair, 1980 \\
\hline Chydorus sp Sars, 1901) & Moinodaphnia macleay (King, 1853) \\
\hline Chydorus barroisi & Nicsmirnovius fitzpatricki \\
\hline Chydorus eurynotus Sars, 1901 & Notoalona sculpta (Sars, 1901) \\
\hline Chydorus nitidulus (Sars, 1901) & Oxyurella ciliata (Bergamin, 1939) \\
\hline Chydorus pubescens Sars, 1901 & Oxyurella sp \\
\hline Chydorus sphaericus (Sars, 1901) & Parvalona parva (Daday, 1905) \\
\hline Coronatella monacantha (Sars, 1901) & Picripleuroxus similis (Vávra, 1900) \\
\hline Coronatella poppei (Richard, 1897) & Streblocerus pygmaeus Sars, 1901 \\
\hline
\end{tabular}


Table 4. Copepoda species registered in sampling from lower Xingu River made in 2013 and 2014.

\begin{tabular}{l}
\hline \multicolumn{1}{c}{ CYCLOPOIDA } \\
\hline Macrocyclops sp Claus, 1893 \\
Thermocyclops minutus (Lowndes), 1934 \\
Thermocyclops inversus Kiefer, 1936 \\
Mesocyclops meridianus (Kiefer), 1926 \\
CALANOIDA \\
Notodiaptomus jatobensis (Wright), 1936 \\
Notodiaptomus isabelae (Wright), 1936 \\
Notodiaptomus oliverai Matsumura-Tundisi et al.,2010 \\
Notodiaptomus dahli (Wright), 1936 \\
Notodiaptomus paraensis Dussart \& Robertson, 1984 \\
Pseudodiaptomus gracilis (F.Dahl, 1894) \\
\hline
\end{tabular}

Table 5. Richness of zooplankton species in different phases of hidrological cycle.

\begin{tabular}{|c|c|c|c|c|}
\hline \multicolumn{5}{|c|}{ Number of zooplankton species registered in 2013} \\
\hline \multicolumn{5}{|c|}{ hydrological period } \\
\hline & rising & flood & lowering & dry \\
\hline Rotifera & 59 & 44 & 53 & 55 \\
\hline Cladocera & 31 & 43 & 39 & 24 \\
\hline Copepoda & 8 & 5 & 3 & 3 \\
\hline Protozoa & 36 & 41 & 38 & 26 \\
\hline TOTAL & 134 & 133 & 133 & 108 \\
\hline \multicolumn{5}{|c|}{ Number of zooplankton species registered in 2014} \\
\hline \multicolumn{5}{|c|}{ hydrological period } \\
\hline & rising & flood & lowering & dry \\
\hline Rotifera & 83 & 52 & 46 & 64 \\
\hline Cladocera & 39 & 50 & 28 & 25 \\
\hline Copepoda & 8 & 5 & 3 & 3 \\
\hline Protozoa & 42 & 36 & 28 & 25 \\
\hline TOTAL & 172 & 143 & 105 & 117 \\
\hline
\end{tabular}

\section{Discussion}

The zooplankton assemblage found in this research showed consistent results in the sampling periods of 2013 and 2014. In general species richness increased during the rising and flood periods being the main contributors Rotifera and Protozoa. On the other hand density increases during the dry period. This was due specially to the groups of Cladocera and Copepoda that have different mechanisms of reproduction than Rotifera and Protozoa. Cladocerans and copepods require an environment less turbulent for its reproduction and development of their populations and they could find this condition during the dry period. It is knowm that some species of cladocerans and copepods produce resting eggs that are deposited in the sediment and at favourable conditions they outburst increasing their density. This fact, probably occurred with Cladocera during the dry period of 2014, where the high density showed by Bosminopsis deitersi was responsible for a high density of total zooplankton.
As pointed out by Lodge (1987) comparative studies that are conducted in a variety of habitats are relevant to demonstrate the community dynamics. Therefore the strategy of sampling in several sites of the lower Xingu River was consistent in revealing the dynamics of zooplankton communities.

Greenwood and Richard-Coulet (1996) discussed how the distribution of species in a river ecosystem is related to adaptative strategies to physical parameters such as, water temperature, flow velocity, water level fluctuations, optiminization of food resources and available living space habitat.

The lower Xingu River is a highly heterogeneous environment consisting of several stretches with bedrocks, macrophyte vegetation and a extensive network of tributaries, (igarapés) wide and complex. A variety of aquatic environments occurs in the river created by several degrees of conectivity and mosaics. This is a factor that enhances diversity of communities, adapted to various conditions of hydraulic stresses, flows, thermal patterns and substrate. The use of a extensive series of measurements in hydrology, water flows, diversity of habitats and sampling of zooplanktonic community was fundamental to understand the spatial and temporal variation of the density/species richness problem. The spatial heterogeneity promotes a succession of communities which take advantage of food habitats. Braided channels such as those found in the lower Xingu river have dense stands of macrophytes (See Abe et al., In press, this volume) that provide protection from disturbances, surfaces for periphyton growth, and abundant food diversity. Macrophytes stands create an aquatic microclimate that affect distribution of organisms and species richness. The quality and quantity of detritus produced in the bedrocks and macrophyte stands and transported by the river offers a wide variety of food available to rotifers, protozoan and other zooplankton species. Open water habitats, dense macrophytes stands, regions of low flows and stagnant waters, are rich in diverse environments enhancing zooplankton diversity. Therefore the spatial heterogneity promotes a diversity of habitats and conditions that enhances zooplankton diversity and species richness. These species are distributed spatially during rising and flood periods, adapting their reproductive strategies to the hydraulic conditions, flows and spatial heterogeneity. This is conspicuous for Cladocera and Copepoda species. Rotifers and protozoan that have not resting eggs, for example shows continuous reproduction strategies during the whole hydrological cycle.

Density of zooplankton decreases during rising and flood period during to the higher dilution. Thus the river discharge, the extensive morphological and hydrological alterations that occur in the lower Xingu river are probably the main cause of the high species richness in this ecosystem.

Processes of long term with pulses that operate at different periods, are the main factor that enhances this diversity. Since the lower Xingu River has no floodplain, the morphology at the river bed the interaction of tributaries with the main river adds to the spatial heterogeneity, 
functioning as a substitute of the floodplain lakes in the várzea (Junk et al., 1989). The zooplankton community is only one example of an ample process that involves all the benthic, fish, periphyton and phytoplankton communities. Significant differences in the aquatic communities at the distinct stages of the hydrological regime occur.

Why there are several endemic species in the aquatic biota of the Amazon River? The hydrogeochemistry of the Amazon basin shows many rivers, lakes and freshwater ecosystems with low conductivity waters and a low degree of mineralization. It is well known from the literature that ionic composition, $\mathrm{pH}$, conductivity of freshwaters are fundamental for the physiological functioning of species of fishes, and aquatic invertebrates in general. This could be one reason for the high degree of endemicity of the freshwater biota in Amazon. However the Amazon region is composed of several varied habitats with differing conditions (Furch, 1984). Several geographical barriers, such as the spatial heterogeneity of the region, the magnitude of water level fluctuations and the interactions terrestrial/aquatic ecosystem may be the cause of geographical isolation and therefore promote endemicity.

\subsection{Future changes in zooplankton}

This paper describes the ecological dynamics of the zooplankton communities in the river ecosystems. With the construction of the two reservoirs at Belo Monte power plant some changes will occur. These can be related to the loss of heterogeneity in habitats considering the flood of the bedrocks and macrophyte stands. Probably the reservoirs will favour the growth and development of Copepoda and Cladocera species that have more conditions to reproduce and growth in lentic environments. Changes in the foodchain can also be expected, since phytoplankton can predominate as food available for zooplankton in the reservoirs. Therefore the zooplankton can change from a lotic community to a lentic community with a predominance of pelagic species. Dumont (2009) reported changes in the diversity and species richness of Nile River zooplankton after the start of operation of the Aswan high dam.

\section{Acknowledgements}

The authors are grateful to the staff of AIIEGA, that participated at the field work and laboratory analysis of the Project Limnological studies and water quality evaluation of the Xingu River.

\section{References}

ABE, DS., SIDAGIS-GALLI, C., MATSUMURA-TUNDISI, T., TUNDISI, JEM., BLANCO, FP., FARIA, CRL. and TUNDISI, JG., In press. Additional list of species of aquatic macrophytes in the lower basin of the Xingu River. Brazilian Journal of Biology = Revista Brasileira de Biologia

ABRIAL, E., RABUFFETTI, AP., ESPÍNOLA, LA., AMSLER, AR., BLETTLER, MCM. and PAIRA, AR., 2014. Influence of hydrological changes on the fish community in two lotic environments of the Middle Paraná Floodplain, Argentina. Aquatic Ecology, vol. 48, no. 3, p. 337-349. http://dx.doi.org/10.1007/ s10452-014-9488-X.

Associação Instituto Internacional de Ecologia e Gerenciamento Ambiental-AIIEGA, 2015. Limnological and water quality studies in the Xingu River in the área of influence of Belo Monte Power Plant. São Carlos: IIEGA. 180 p + anexos. Report, VII and VIII.

BITTENCOURT, MM. and AMADIO, SA., 2007. Proposta para identificação rápida dos períodos hidrológicos em áreas de várzea do Rio Solimões - Amazonas nas proximidades de Manaus. Acta Amazonica, vol. 37, no. 2, p. 307-312. http://dx.doi.org/10.1590/ S0044-59672007000200019.

BLETTLER, MCM., AMSLER, ML. and DRAGO, IE., 2012. Hydraulic factors controlling the benthic invertebrate distribution within and among dunes of middle Paraná River (Argentina) and sampling techniques. Journal of South American Earth Sciences, vol. 35, p. 27-37. http://dx.doi.org/10.1016/j.jsames.2011.11.003.

BRITO, CSA., 2008. Variação espaço temporal do zooplancton em diferentes ambientes do médio Rio Xingú, PA. Belém: Universidade Federal do Pará. 79 p. Masters Dissertation in Animal Science.

CARVALHO, MC., 1983. Efeitos da flutuação do nível da água sobre a densidade e composição do zooplancton em um lago da varzea da Amazonia, Brasil. Acta Amazonica, Manaus, vol. 13, no. 5-6, p. 715-724.

DUMONT, HJ., 2009. The crustacean zooplankton (Copepoda, Branchiopoda) Atynid Decapoda and Syncaride of the Nile Basin. In DUMONT, HJ. (Ed.). The Nile: origin environments and human use. Berlin: Springer. p. 547-562.

FURCH, F., 1984. Water chemistry of the Amazon basin. The distribution of chemical elements among freshwaters. In SIOLI, H. (Ed.). The Amazon. Limnology and handscape ecology. Dordrecht: Dr. W. Junk Publishers. p. 168-199. Monographae Biologicae, no. 56.

GREENWOOD, MT. and RICHARD-COULET, M., 1996. Aquatic Invertebrates. In PETTS, GE. and AMOROS, C. (Eds.). Fluvial hydrosystems. London: Chapman \& Hall. p. 138-166.

JUNK, WJ., BAYLEY, PB. and SPUNKS, RE., 1989. The flood pulse concept in river flood plain systems. Canadian Special Publication of Fisheries and Aquatic Sciences, vol. 196, p. 110-127.

LODGE, D., 1987. Spatial heterogeneity and habitat interactions in lake communities. In CARPENTER, SR. (Ed.). Complex interactions in lake communities. Berlin: Springer-Verlag. p. 181-208.

MATSUMURA-TUNDISI, T. and TUNDISI, JG., 2007. Occurrence of Pseudodiaptomus gracilis (F.Dahl, 1894), Copepoda, Calanoida in amamzoniam fresh waters. Brazilian Journal of Biology $=$ Revista Brasileira de Biologia, vol. 67, no. 3, p. 585-586. http:// dx.doi.org/10.1590/S1519-69842007000300029. PMid:18094847.

PETTS, GE. and AMOROS, C., 1996. Fluvial hydrosystems. London: Chapman \& Hall. 322 p.

TUNDISI, JG, MATSUMURA-TUNDISI, T.,TUNDISI, JEM., FARIA, CRL., ABE, DS., BLANCO, F., RODRIGUES-FILHO, J., CAMPANELLI, LC., SIDAGIS-GLLI, C., TEIXEIRA-SILVA, V., DEGANI, MR., SOARES, FS. and GATTI JUNIOR, PL. In press. Limnological and ecological methods: approaches and sampling strategies in the área of lower Xingu River and in the área of influence of future Belo Monte Power Plant. Brazilian Journal of Biology $=$ Revista Brasileira de Biologia . 